\title{
Preliminary Report on the James Bayou Survey: A Search for Sha- Childni-Ni (1795-1840)
}

Claude McCrocklin

Unknown

Follow this and additional works at: https://scholarworks.sfasu.edu/ita

Part of the American Material Culture Commons, Archaeological Anthropology Commons, Environmental Studies Commons, Other American Studies Commons, Other Arts and Humanities Commons, Other History of Art, Architecture, and Archaeology Commons, and the United States History Commons

Tell us how this article helped you.

This Article is brought to you for free and open access by the Center for Regional Heritage Research at SFA ScholarWorks. It has been accepted for inclusion in Index of Texas Archaeology: Open Access Gray Literature from the Lone Star State by an authorized editor of SFA ScholarWorks. For more information, please contact cdsscholarworks@sfasu.edu. 


\section{Preliminary Report on the James Bayou Survey: A Search for Sha-Childni-Ni}

(1795-1840)

\section{Creative Commons License}

\section{(c) (i) (9)}

This work is licensed under a Creative Commons Attribution-NonCommercial 4.0 International License 
Volume 9, Number 1

\title{
Preliminary Report on the James Bayou Survey: A Search for Sha-Childni-Ni (1795-1840)
}

\author{
Claude McCrocklin, \\ Shreveport LA
}

\section{Foreword}

This is a preliminary report on an archaeological survey of the James Bayou area of Marion County, Texas that started in February, 1998 and is still continuing. The primary goal of the survey was to find the location of the large 1795-1840 Caddo Indian village called by them Sha-Childn$\mathrm{Ni}$ (Timber Hill). Historical research and two early maps of 1811 and 1841 clearly show the village on the south side of James Bayou (Figures 1 and 2). The sites found prove that both maps are right. This is a report on Sites 2 and 3 of the four sites found to date. [Ed. note: A fifth site has been found since this report was completed.] When the survey is complete, all sites found will be plotted on a map so that we can see Sha-Childn-Ni emerge from the hills and woods along both sides of James Bayou. Thereby, the site of the last Caddo Indian village in their native homeland will be preserved for all to see and appreciate. If this survey can contribute to Caddo heritage in this way, it will have accomplished its purpose. [Ed. note: These sites (or site complex) have not yet been assigned site numbers.]

\section{Introduction}

Three of the four sites found and identified on James Bayou are single component with no material later than the 1840 s. The fourth site has an Anglo component that dates past the Civil War period. Artifacts from the single component sites are consistent with those recovered from other historic Indian sites in the area and with those from Sulphur Ford Trading Past from which they probably came. This not only helps identify the sites, but also shows that there was interaction with other Indian tribes such as the Coushatta along Red River and Caddo Lake. 


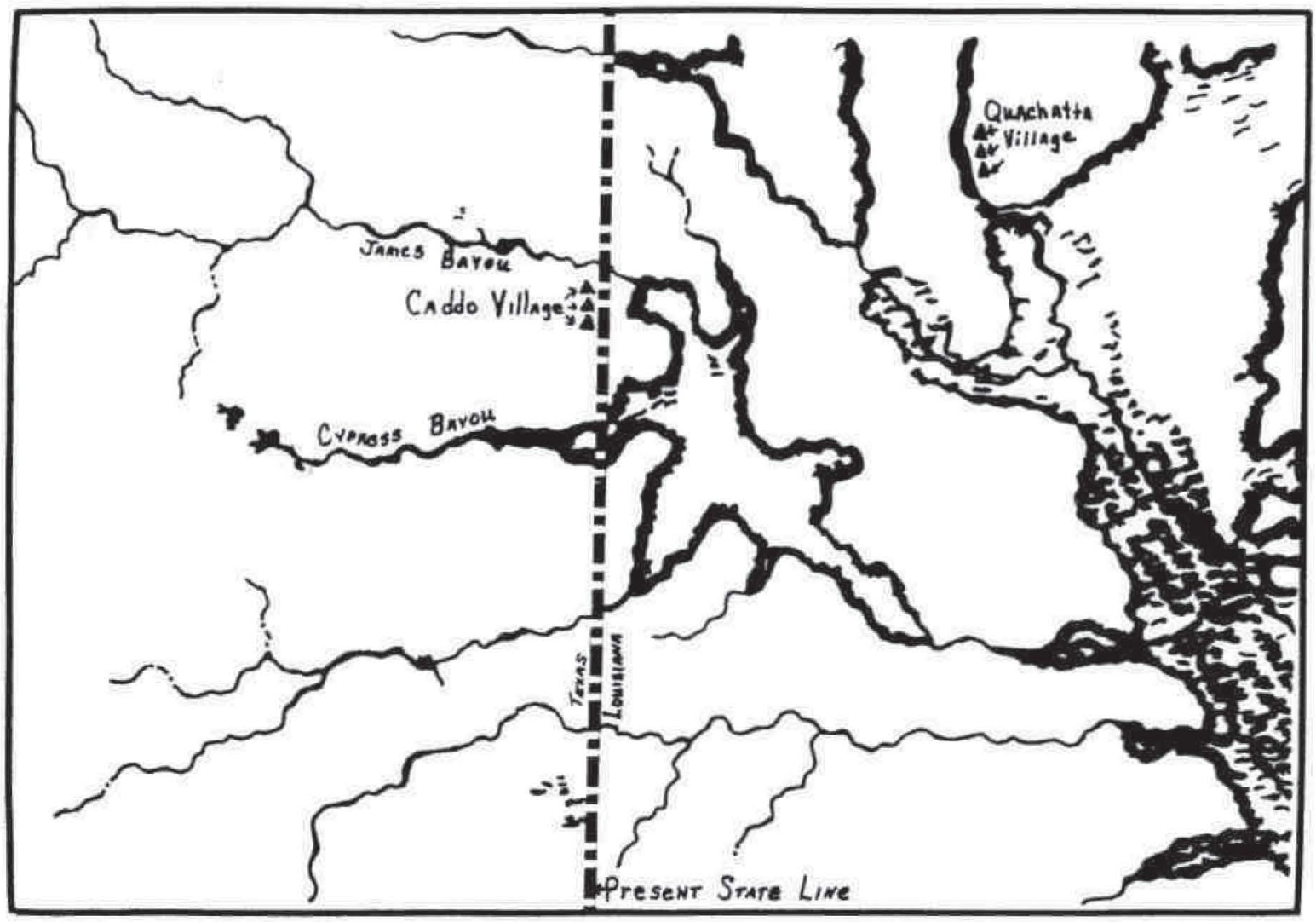

Figure 1. 1811 Map Showing the Location of the Caddo Village on James Bayou (Adapted from Darby).

\section{Topography}

Most of the southern side of James Bayou is high hills with ridge points extending into the flood plain. These are interspersed with small streams and valleys, all of which are densely wooded. The exception is large, cut over areas now grown up into thickets and brush. Before this, the land was plowed farmland for 100 or more years. We found plow points all over the area surveyed. The combination of years of plowing has disturbed sites, and dense woods reduce surface visibility, making the 200 year old sites hard to find. Fortunately, these are large sites and can be found with persistence and know how. 


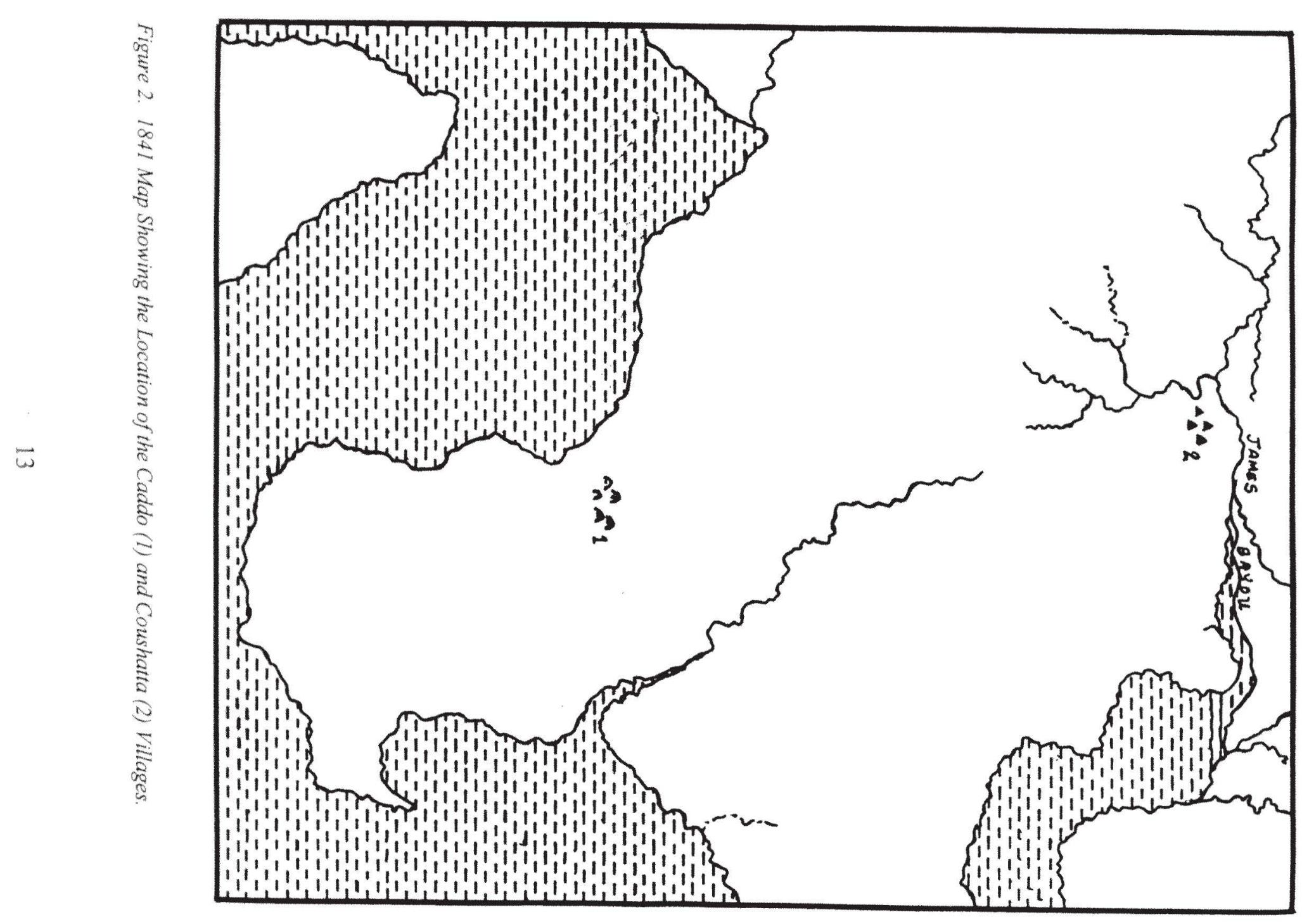




\section{Methods}

Shovel tests $(1 \times 1 \mathrm{~m})$ and metal detector scans (in transects, then in a grid pattern) were the principal methods used. The area previously has been timbered and plowed, but is currently covered by dense woods, thickets, and swamps. Once a site was located, light shovels and trowels were used to excavate $5 \mathrm{~cm}$ levels to sterile clay (about $20 \mathrm{~cm}$ ) in the thin top soil of the ridge points. Screening was not possible due to the wet conditions during February and March.

\section{Site Descriptions}

The four sites found to date are located in varied terrain with one in flatland, two on ridge points, and one on a hill top (Figure 3). All are near a spring or stream that flows into James Bayou. We have not found any sites on James Bayou itself. Also, the ridge point sites are well back from the point itself and uphill. Why this is so is unknown. The exact size of the sites, although they are large, is not known because we only tested them. We did measure the artifact scatter on sites 2 and 3 by pacing. They were approximately $90 \mathrm{x}$ 40 paces (about one meter/pace).

The presence or number of features such as house floors and high activity areas was not determined because we only tested them. These are large, but fragile, sites with an average depth of only $0-20 \mathrm{~cm}$. Thus, stratigraphy is problematical in the thin top soil that covers the ridge points where the sites are located.
The presumed function of the sites is that they are complexes of family dwellings with thatched roofs and upright pole walls such as pictured in the 1860 Soule photograph of a Caddo hamlet in Oklahoma. We found evidence of this on Site 1, the only site that we extensively tested. This is based upon post molds, daub imprinted with twigs and sticks, absence of a chimney or hearth, and a sparse square nail scatter. Instead of a hearth or chimney, there were small fire pits in the house floors. These contained charred bone bits, ash and charcoal, and were presumed to be for cooking and heating.

Near and on all of the sites were "out of place" patches of swamp grass. Because "swamp" grass, as the name implies, grows in swamps or wetland in its natural state, we think this swamp grass is descended from that brought by the Caddos to thatch their houses on the 200-foot high hills. 


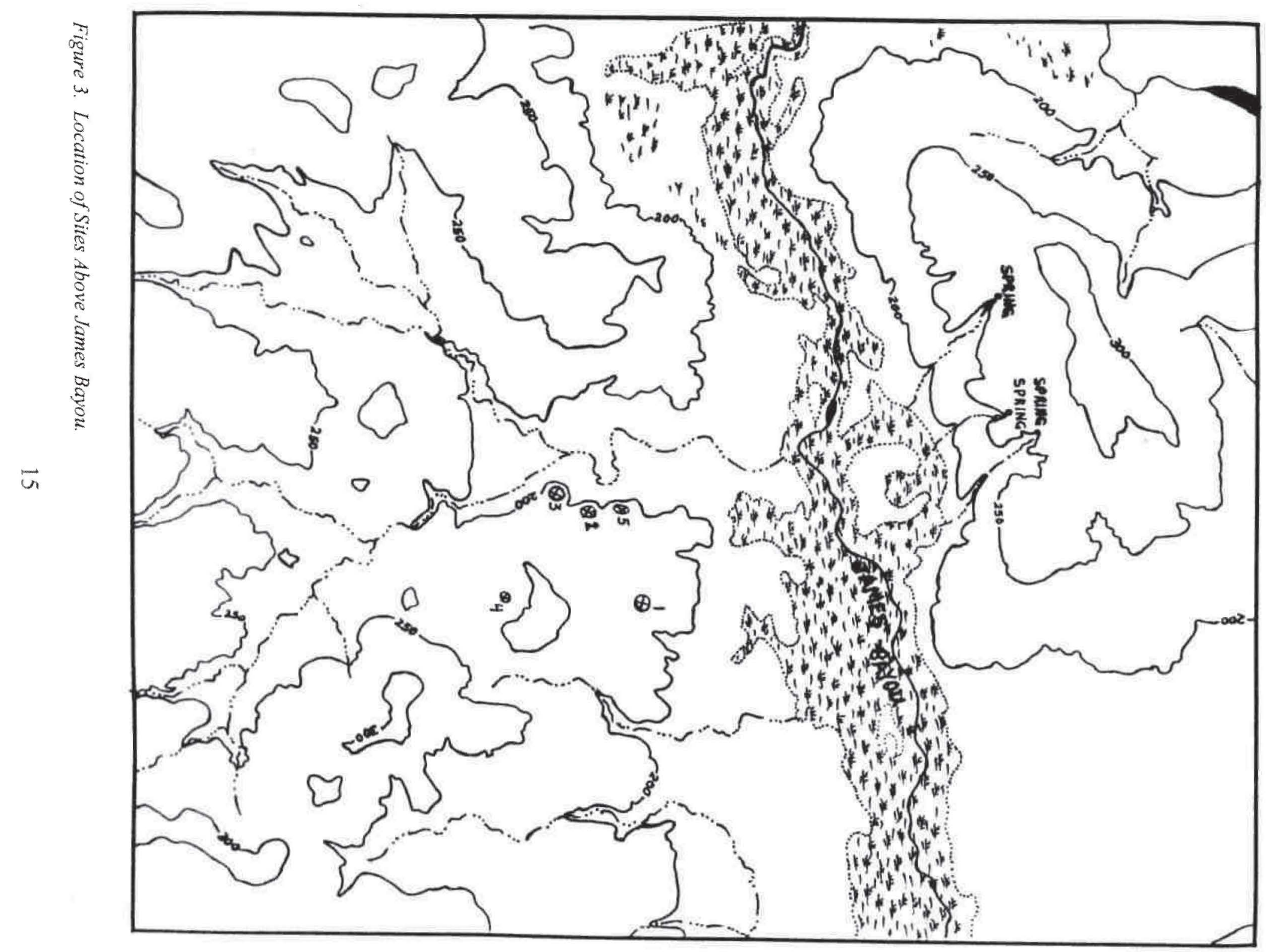




\section{Artifacts Found}

At the time of this report, no professional analysis of the artifacts has been made, so they simply will be listed with a brief description.

\section{Native American Artifacts}

Pot sherds: All are small sherds found in and around house floors. Most are plain red color with some in some buff and black. The temper is varied, with shell, bone, or grog. Some sherds have both shell and bone temper.

Metal arrowpoints: We have found two to date (Figure 4). One is iron with long barbs and a triangular point. The other is rolled copper, cone shaped. This type has also been found on Coushatta sites along Red River and Caddo Lake.

Copper cutouts: Only fragments were found. They are made from the same sheet copper as the arrowpoints.

Chipped European ceramics and glass: These were made by chipping one or two sides of a sherd. Some are pressure flaked.

Tools made from nails: An assortment of small chisels, punches, and hooks.

\section{Trade Goods}

Flintlock gun parts: A lock plate, tumbler, part of a gun barrel, a brass ramrod tip with wood still inside, and a "worm" screw used to clean the bore or extract a stuck bullet.
Lead bullets: These are round lead musket or rifle balls of various calibers. Some have been shot and flattened, probably reflecting extraction from a target, game, etc.

Gun flints: Two were found, one English and one French.

Bells: Two were found, one a small "goat" bell type, the other a $4 \mathrm{~cm}$ sized, conventional bell shape.

European ceramics: These are English made green and blue shell edge, polychrome, banded, mocha, transfer print, and dendritic wares. European ceramics and glass were not plentiful on Sites 2 and 3.

Bottle glass: Of the sparse amount found, most fragments were dark green wine bottle, blue-green molded brandy bottle, amber bottle, and pale blue medicine vial types.

Earthenware: Gray salt glazed and reddish brown glazed with red interior sherds were found.

Utensils: Two-tine forks, case knives, iron spoons; only fragments found.

Kettles: These were three legged iron French type with pointed ears; parts of three sizes were found. 


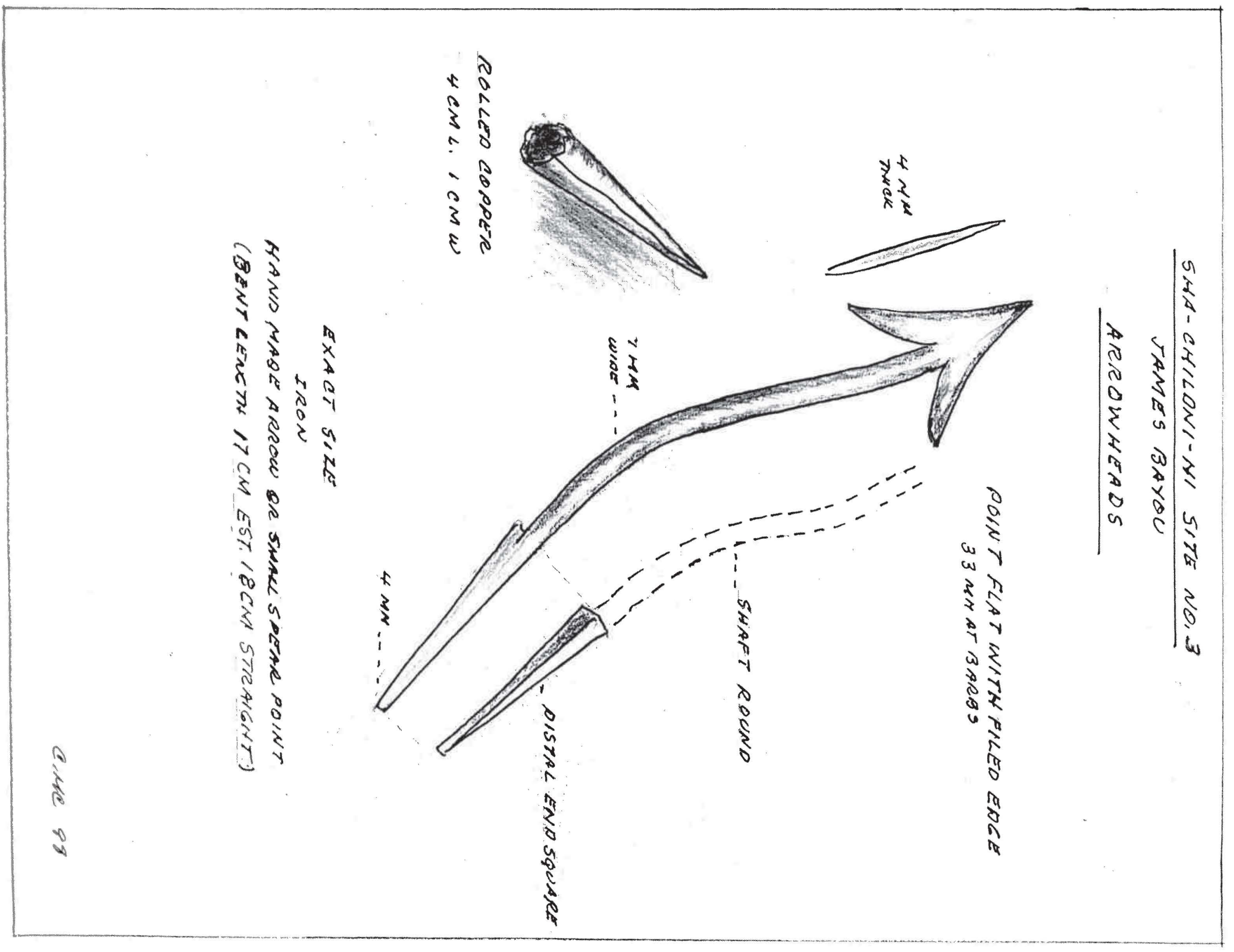


Horse gear: Three Spanish type bridle bits, buckles, and cinches were found.

Tobacco pipes: These were parts of elbow pipes. One had " $\mathrm{X}$ " marks; this was the same as some found at Sulphur Fort
Trading Post and at Coushatta Village.

Miscellaneous items: Brass thimble, brass spigot, brass button with back mark, numerous copper cuttings and scraps, lead spillage, and unidentified iron object.

\section{Summary}

Our goal was to find the James Bayou Kadohadacho village of 1795-1840. As of this report, we know that we have found a significant part of it --- just how much of it remains to be seen. We have paused looking for new sites until we can get a handle on the ones already found, especially sites 2 and 3 of this report. When we think we have done this, someone finds artifacts 15 or 20 meters away, and we have another component. It should be noted that we are only testing for an artifact sample and to determine site size. We have not found, nor looked for, a major feature. Finding those will be left to whoever excavates the sites. Also, since no Caddo sites that we know of have been found and reported on from this period, we have nothing to compare with. Everything that we find is a first, particu-larly the site layout, and must be puzzled out. We cannot help but feel that the data and artifacts from this survey will contri-bute significantly to the understanding of the late historical Caddo Indians in northeastern Texas.

\section{Acknowledgment}

First, thanks to Jacques Bagur for his research and abiding interest in Caddo Village, to Bill Hughes to International Paper Company who gave permission to survey their land, and to Jess $M$. DeWare $I V$ of the Cypress Valley Alliance of Jefferson, Texas, who sponsored the project.
Next, I acknowledge the Louisiana Archaeological Society survey crew who went into the field and did the work. They are: Roger Hooper, president of the LAS chapter in Shreveport (Field Secretary), Ruth Rainey, Charles Shankles of Potters Point and Dallas, Pam Stanfield, Danny Stanfield, David Hartzo, and Craig Kennedy. 


\section{References}

Bagur, Jacques

1991 The Location of the Caddo Indian

Village. Corps of Engineers Publication, Waterways Experiment Station, Vicksburg.

Flores, Dan L.

1984 Jefferson and Southwestern Exploration: The Freeman and Custis Accounts of the Red River Expeditions of 1806. University of Oklahoma Press, Norman.

Glover, William B.

1932 A History of the Caddo Indians.
Masters thesis, University of Texas, Austin.

Sibley, John

1805 Historical Sketches of Several Indian Tribes in Louisiana. In: Message from the President of the United States, Communicating Discoveries Made in Exploring the Missouri, Red River, and Washita, by Captains Lewis and Clarke, Doctor Sibley, and Mr. Dunbar, with a Statistical Account of the Countries Adjacent. American State Papers, Class II, Indian Affairs. Gale and Setton, Washington, DC. 